\title{
STANDARISASI DAN SKRINING FITOKIMIA EKSTRAK ETANOL 70\% DAUN JERUK LIMAU (Citrus amblycarpa (Hassk.) Osche)
}

\author{
G. M. D. Putra*, D. A. Satriawati, N. K. W. Astuti, dan A. A. G. R. Yadnya-Putra
}

Program Studi Farmasi Fakultas Matematika dan Ilmu Pengetahuan Alam Universitas Udayana

*E-mail: mahendradharmap97@gmail.com

\begin{abstract}
ABSTRAK
Jeruk limau (Citrus amblycarpa (Hassk.) Osche) merupakan tanaman endemik Indonesia yang memiliki potensi besar sebagai obat. Pendekatan kemotaksonomi terhadap daun C. amblycarpa dilakukan untuk memprediksi potensinya dalam pengobatan. Sebelum dilakukan pengujian aktivitas farmakologi, serbuk dan ekstrak yang diperoleh dari hasil ekstraksi menggunakan pelarut etanol $70 \%$ terlebih dahulu dilakukan studi pendahuluan meliputi perhitungan persentase rendemen ekstrak, pemeriksaan organoleptik dan mikroskopik serbuk, standarisasi serbuk dan ekstrak, dan skrining fitokimia untuk mengetahui kandungan metabolit sekunder dari daun C. amblycarpa. Standarisasi yang dilakukan meliputi penetapan kadar abu total, penetapan kadar abu tidak larut asam, penetapan kadar abu larut air, dan penetapan kadar air dari serbuk simpilisa dan ekstrak. Skrining fitokimia terhadap ekstrak etanol $70 \%$ daun C. amblycarpa meliputi pemeriksaan alkaloid, pemeriksaan flavonoid, pemeriksaan polifenol dan tanin, pemeriksaan glikosida, pemeriksaan steroid dan triterpenoid, pemeriksaan saponin, serta pemeriksaan minyak atsiri. Hasil skrining fitokimia menunjukkan bahwa ekstrak etanol $70 \%$ daun C. amblycarpa mengandung senyawa golongan flavonoid, polifenol dan tanin, glikosida, serta minyak atsiri.
\end{abstract}

Kata Kunci: Citrus amblycarpa (Hassk.) Osche, jeruk limau, standarisasi, skrining fitokimia

\begin{abstract}
Lime (Citrus amblycarpa (Hassk.) Osche) is an Indonesian endemic plant that has great potential as a medicine. The chemotaxonomic approach of $C$. amblycarpa leaves was conducted to predict its potency to be medicine. Prior to the pharmacological activities, preliminary study of powder and extract that obtained from the extraction using ethanol $70 \%$ as solvent should be carried out, including calculation of percentage of extract yield, organoleptic and microscopic test, standardization for powder and extract, and phytochemical screening to find out the secondary metabolites content of $C$. amblycarpa leaves. Standardization that has been conducted include determination of total ash content, acid-insoluble ash content, water-soluble ash content, and determination of water content for both simplicia powder and extract. Phytochemicals screening for the etanol $70 \%$ extract of of C. amblycarpa leaves included alkaloid examination, flavonoid examination, polyphenol and tannin examination, glycoside examination, steroid and triterpenoid examination, saponin examination, and essential oil examination. The results of phytochemicals screening showed etanol $70 \%$ extract of $C$. amblycarpa leaves contained flavonoid compounds, polyphenols and tannins, glycoside, and also Citrus essential oil.
\end{abstract}

Keywords: Citrus amblycarpa (Hassk.) Osche, lime, standardization, phytochemicals screening

\section{PENDAHULUAN}

Indonesia merupakan salah satu negara yang memiliki keanekaragaman hayati yang tinggi. Dilaporkan bahwa ditemukan 38.000 jenis tanaman dimana 55\%-nya merupakan tanaman endemik Indonesia (Triyono, 2013). Masyakarat Indonesia telah terbiasa menggunakan tanaman sebagai obat-obatan dikarenakan kemudahan dalam memperoleh dan membudidayakannya. Salah satu tanaman yang digunakan sebagai obat tradisional adalah jeruk limau. Jeruk limau (Citrus amblycarpa (Hassk.) Osche) merupakan tanaman endemik Indonesia yang berasal dari famili Rutaceae, genus Citrus. Tanaman yang berasal dari genus Citrus sudah sangat umum digunakan oleh masyarakat di seluruh dunia untuk pengobatan berbagai penyakit. Banyak penelitan telah membuktikan aktivitas yang dimiliki tanaman genus Citrus meliputi aktivitas sebagai antioksidan, hepatoprotektif, kardiovaskular, antibakteri, antiinflamasi, antitumor, dan antiviral (Yi et al., 2017; Jaiswal et al., 2015). Pemanfaatan jeruk limau untuk pengobatan juga telah banyak diterapkan oleh masyarakat Bali. Menurut Lontar Usada Taru Pramana dikatakan $C$. amblycarpa telah digunakan secara turun temurun untuk mengobati kram dan kesemutan (Putra, 1999). 
Dengan dilakukan pendekatan kemotaksonomi untuk pengembangan obat baru, diduga bahwa C. amblycarpa memiliki potensi besar untuk dikembangkan menjadi obat alternatif. Penelitian yang telah dilakukan oleh Mulyani dan Hutabarat (2009) membuktikan adanya aktivitas antibakteri $C$. amblycarpa dengan konsentrasi hambat minimal $0,312 \% \mathrm{v} / \mathrm{v}$ untuk minyak atsiri buah, dan $0,039 \% \mathrm{v} / \mathrm{v}$ untuk minyak atsiri daun terhadap $S$. aureus.

Maka dari itu sebelum dilakukan pengujian aktivitas lainnya terhadap tanaman C. amblycarpa, diperlukan studi tahap awal yakni standarisasi serbuk simplisia dan ekstrak sesuai dengan syarat umum mutu baku simplisia yang tercantum pada Farmakope Herbal Indonesia (Depkes RI, 2008). Namun, dalam FHI belum tercantum monografi $C$. amblycarpa, maka dari itu hasil stadarisasi pada penelitian ini nantinya dapat dijadikan sebagai parameter acuan terhadap mutu simplisia dan ekstrak C. amblycarpa. Selain itu juga diperlukan penapisan (skrining) fitokimia untuk mengetahui kandungan senyawa metabolit sekunder yang ada pada daun $C$. amblycarpa. Skrining fitokimia juga dapat dijadikan sebagai dasar untuk mengetahui profil bioaktivitas dari $C$. amblycarpa (Wadood et al., 2013; Buhian et al., 2016).

Pada tahapan ekstraksi, pemilihan pelarut sangat mempengaruhi keberhasilan tahap standarisasi dan skrining fitokimia ekstrak. Pada penelitian ini bagian daun $C$. amblycarpa dipilih sebagai sampel dikarenakan kemudahan dalam proses pengumpulan. Selain itu bagian daun tanaman genus Citrus juga terkonsentrasi senyawa fitokimia yang berpotesi sebagai obat alternatif (Samraj dan Rajamurgugan, 2017). Setelah diperoleh serbuk simplisia dan ekstrak sesuai dengan persyaratan yang ditentukan serta telah diketahui golongan senyawa fitokimia yang terkandung, maka sampel yang diperoleh nantinya dapat digunakan untuk pengujian tahap selanjutnya.

\section{MATERI DAN METODE \\ Bahan}

Bahan-bahan yang digunakan yaitu daun tua C. amblycarpa (Hassk.) Osche, etanol 70\% berderajat teknis (Bratachem®), akuades, larutan kloralhidrat, reagen Mayer, reagen Bouchardat, larutan besi (III) klorida $\left(\mathrm{FeCl}_{3}\right)$, aseton $\mathrm{P}$ (Merck®), toluena $\mathrm{P}$ (Merck®), serbuk asam borat $\mathrm{P}\left(\right.$ Merck $\left.{ }^{\circledR}\right)$, serbuk asam oksalat $\mathrm{P}($ Merck®), asam asetat anhidrat $\mathrm{P}$ (Merck®), kloroform P (Merck®), asam sulfat P (Merck®), dan eter P (Merck®).

\section{Peralatan}

Toples kaca gelap, pisau, pengayak stainless 60 mesh, blender (Sharp $\left.{ }^{\circledR}\right)$, seperangkat alat gelas (Pyrex $\left.{ }^{\circledR}\right)$, mikroskop cahaya, hot plate (FischerScientific $($ ), vacuum rotary evaporator (Eyela $\left.{ }^{\circledR}\right)$, oven (Binder $\left.{ }^{\circledR}\right)$, UV-lamp cabinet (CAMAG®), alat tanur (WiseTherm ${ }^{\circledR}$ ), krus porselen, pipet tetes dan kertas saring bebas abu (Whattman ${ }^{\circledR}$ ).

\section{Cara Kerja}

Determinasi Tanaman C. amblycarpa

Sampel dikumpulkan dari Desa Kemenuh, Kecamatan Sukawati, Gianyar, Bali. Determinasi tanaman dilakukan melalui pengiriman bagian tanaman lengkap, meliputi akar, batang, daun muda dan tua, buah, dan bunga pada Balai Konsevasi Tumbuhan Kebun Raya 'Eka Karya'-Lembaga Ilmu Pengetahuan Indonesia (LIPI), Candikuning, Tabanan, Bali.

\section{Preparasi Serbuk dan Pembuatan Ekstrak Etanol 70\% Daun C. amblycarpa}

Daun yang terkumpul dibersihkan dan dikeringkan, kemudian diserbukkan dengan menggunakan blender. Lalu diayak dengan pengayak 60 mesh (Depkes RI, 2008). Serbuk dikemas dalam toples tertutup rapat dan terhindar dari cahaya secara langsung.

Ekstrak dibuat dengan menggunakan metode maserasi, dilakukan dengan merendam serbuk daun $C$. amblycarpa sebanyak $500 \mathrm{mg}$ dalam pelarut etanol $70 \%$ sebanyak $5 \mathrm{~L}$ selama 3 hari. Maserat kemudian disaring, lalu filtrat diuapkan dengan menggunakan vacuum rotatory evaporator $\left(60^{\circ} \mathrm{C} ; 50 \mathrm{rpm}\right)$. Hasil rotav dituang ke dalam loyang dan dimasukkan ke dalam oven dengan suhu $40^{\circ} \mathrm{C}$ hingga diperoleh ekstrak kental.

\section{Pengamatan Organoleptis dan Mikroskopis Simplisia dan Ekstrak Etanol 70\% Daun C. amblycarpa}

Dilakukan pengamatan organoleptic serbuk simplisia dan ekstrak etanol $70 \%$ daun $C$. amblycarpa yang meliputi pengamatan organoleptis (bentuk, warna, bau, dan rasa). Pengamatan fragmen pengenal secara mikroskopis dilakukan dibawah mikroskop cahaya. 


\section{Standarisasi Serbuk dan Ekstrak Etanol 70\% Daun C. amblycarpa}

1. Penetapan kadar abu total serbuk dan ekstrak etanol $70 \%$ daun C. amblycarpa dilakukan dengan menimbang 2 sampai 3 gram bahan uji dimasukkan ke dalam krus silikat yang telah dipijar dan ditara, dipijarkan hingga arang habis, didinginkan dan ditimbang. Kemudian dipijarkan kembali hingga memperoleh bobot tetap, selanjutnya tahap ini diulangi sebanyak 3 kali setelah itu dihitung kadar abu total (Depkes RI, 1995).

2. Penetapan kadar abu tidak larut asam serbuk dan ekstrak dilakukan dengan cara mendidihkan abu yang diperoleh pada penetapan kadar abu dengan $25 \mathrm{~mL}$ asam klorida $10 \%$ selama 5 menit, lalu dikumpulkan bagian yang tidak larut asam dan disaring menggunakan kertas saring bebas abu. Hasil saring lalu dicuci menggunakan air panas dan dipijarkan dengan suhu $600^{\circ} \mathrm{C}$ hingga bobot tetap. Abu yang diperoleh lalu ditimbang dan dihitung kadar abu tidak larut asam (Depkes RI, 1995).

3. Penetapan kadar abu yang larut air untuk serbuk dan ekstrak dilakukan dengan cara mendidihkan abu yang diperoleh pada penetapan kadar abu dengan $25 \mathrm{~mL}$ air selama 5 menit, lalu dikumpulkan bagian yang tidak larut dan disaring menggunakan kertas saring bebas abu, hasil saringan dicuci dengan air panas dan dipijarkan selama 15 menit pada suhu $400^{\circ} \mathrm{C}$. Abu yang diperoleh lalu ditimbang dan dihitung kadar abu tidak larut asam (Depkes RI, 1995).

4. Penetapan kadar air serbuk dan ekstrak etanol 70\% daun C. amblycarpa dilakukan dengan menggunaan metode destilasi toluena. Ditimbang sejumlah bahan yang mengandung $1-4 \mathrm{~mL}$ air, dimasukkan ke dalam labu. Dimasukkan $200 \mathrm{~mL}$ toluena jenuh air ke dalam labu. Destilasi dilakukan selama 15 menit dan diamati volume air yang terpisah dari ekstrak (Depkes RI, 1995). Dihitung persentase kadar air serbuk dan ekstrak.

\section{Skrining Fitokimia Ekstrak Etanol 70\% Daun C. amblycarpa.}

Pembuatan larutan uji fitokimia dilakukan dengan cara melarutkan $200 \mathrm{mg}$ ekstrak kental dengan $25 \mathrm{~mL}$ etanol $70 \%$.
1. Pemeriksaan Alkaloid

Larutan uji diuapkan sebanyak $2 \mathrm{~mL}$, kemudian residu dilarutkan dalam $4 \mathrm{~mL}$ $\mathrm{HCl} 2 \mathrm{~N}$. Lalu larutan dibagi kedalam 4 tabung rekasi yaitu tabung A, B, C dan D. Tabung A sebagai blanko ditambahkan $\mathrm{HCl} 2 \mathrm{~N}$, tabung B ditambahkan pereaksi Mayer sebanyak 3 tetes, tabung $\mathrm{C}$ ditambahkan pereaksi Wagner sebanyak 3 tetes dan tabung D ditambahkan perekasi Bouchardat sebanyak 3 tetes. Endapan putih yang terbentuk pada tabung B, terbentuk endapan pada tabung $\mathrm{C}$, dan terbentuk endapan coklat kehitaman pada tabung D menandakan adanya alkaloid (Depkes RI, 1995).

2. Pemeriksaan Flavonoid

Sebanyak $1 \mathrm{~mL}$ larutan uji diuapkan, residu dibasahkan dengan aseton $P$. Ditambahkan 1 gram asam borat $\mathrm{P}$ dan asam oksalat P. Larutan dipanaskan hatihati di atas tangas air dengan menghindari pemanasan berlebihan. Sisa yang diperoleh dicampur dengan $10 \mathrm{~mL}$ eter P. Larutan yang berflouresensi kuning intensif di bawah sinar UV $366 \mathrm{~nm}$ menandakan adanya flavonoid (Depkes RI, 1995).

3. Pemeriksaan Polifenol dan Tanin

Sebanyak $3 \mathrm{~mL}$ larutan uji dibagi kedalam 3 bagian yaitu tabung A, B, dan C. Tabung A digunakan sebagai blanko, tabung $\mathrm{B}$ direaksikan dengan larutan besi (III) klorida $10 \%$, dan tabung $\mathrm{C}$ direaksikan dengan larutan besi (III) klorida 5\%. Terbentuknya warna biru tua atau hitam kehijauan pada tabung B menunjukkan adanya polifenol, dan terbentuknya warna biru kehijauan pada tabung $\mathrm{C}$ menunjukkan adanya tanin (Vijayalakshmi dan Ravindhran, 2012).

4. Pemeriksaan Glikosida

Larutan uji sebanyak $1 \mathrm{~mL}$ diuapkan, residu dilarutkan dengan $5 \mathrm{~mL}$ asam asetat anhidrat, ditambahkan dengan 10 tetes asam sulfat. Terbentuknya endapan biru atau hijau menandakan adanya glikosida (Depkes RI, 1995)

5. Pemeriksaan Steroid dan Triterpenoid Larutan uji sebanyak $2 \mathrm{~mL}$ diuapkan, residu dilarutkan dengan $0,5 \mathrm{~mL}$ kloroform, ditambahkan $0,5 \mathrm{~mL}$ asam asteat anhidrat. Ditambahkan $2 \mathrm{~mL}$ asam sulfat $\mathrm{P}$ melalui dinding tabung. Terbentuknya cincin biru kehijauan menandakan adanya steroid dan cincin 
kecoklatan atau violet menandakan adanya triterpenoid.

6. Pemeriksaan Saponin

Larutan uji sebanyak $10 \mathrm{~mL}$ dikocok vertikal dalam tabung reaksi selama 10 detik kemudian dibiarkan selama 10 detik. Pembentukan busa setinggi 1-10 cm yang stabil akan terbentuk selama tidak kurang dari 10 menit. Setelah itu ditambahkan 1 tetes $\mathrm{HCl} 2 \mathrm{~N}$, jika busa tersebut tidak hilang menunjukkan adanya saponin (Depkes RI, 1995).

7. Pemeriksaan Minyak Atsiri

Larutan uji sebanyak $1 \mathrm{~mL}$ diuapkan hingga diperoleh residu. Hasil positif ditunjukkan dengan adanya aroma khas yang dihasilkan oleh residu (Ciulei, 1984).

\section{HASIL DAN PEMBAHASAN}

\section{Determinasi Jenis Tumbuhan}

Determinasi tanaman C. amblycarpa (Hassk.) Osche dilakukan untuk memastikan apakah tanaman yang digunakan memang benar merupakan tanaman yang diinginkan (Laksmiani et al., 2015). Hasil determinasi menunjukkan klasifikasi $C$. amblycarpa (Hassk.) Osche sebagai berikut: Kingdom: Plantae, Divisi: Spermatophyta; Sub divisi: Angiospermae; Kelas: Dicotyledoneae; Ordo: Sapindales; Famili: Rutaceae; Genus: Citrus, Spesies: Citrus amblycarpa (Hassk.) Osche.

\section{Preparasi Serbuk dan Pembuatan Ekstrak Etanol 70\% daun C. amblycarpa}

Setelah melalui tahap pengecilan ukuran partikel, digunakan pengayak Mesh 60 untuk homogenisasi ukuran partikel dan menghasilkan serbuk berderajat halus. Semakin halus serbuk yang dihasilkan maka ekstraksi yang dilakukan akan semakin efektif (Diniatik, 2015).

Pembuatan ekstrak kental daun $C$. amblycarpa dengan metode maserasi menggunakan pelarut etanol $70 \%$, dan dilakukan remaserasi sebanyak 2 kali. Maserasi merupakan suatu metode penyarian sederhana dengan cara perendaman sampel pada suhu ruangan untuk mencegah kerusakan senyawa yang terkandung didalamnya. Kelarutan suatu senyawa dalam pelarut mengikuti prinsip like dissolves like, yang mana senyawa polar akan tertarik untuk larut pada pelarut polar sedangkan senyawa non polar cenderung akan tertarik ke pelarut non- polar (Seidel, 2008; Wells, 2003). Etanol merupakan pelarut universal, yakni dengan indeks polaritas 5,2 sehingga dapat menarik secara baik senyawa polar maupun non polar (Poelongan et al., 2007). Selain itu menurut Farmakope Herbal Indonesia, jika tidak dinyatakan lain pelarut yang digunakan untuk maserasi ekstrak simplisia adalah etanol $70 \%$ (Depkes RI, 2008). Proses pemisahan pelarut dan ekstrak dilakukan dengan menggunakan vacuum rotatory evaporator untuk dapat memisahkan pelarut dan ekstrak dengan suhu dibawah titik didih pelarut sehingga resiko rusaknya ekstrak karena suhu terlalu tinggi dapat dihindari (Damayanti dan Fitriana, 2012). Setelah diuapkan, ekstrak dituang ke dalam loyang dan dimasukkan ke dalam oven dengan suhu $40^{\circ} \mathrm{C}$ sehingga diperoleh ekstrak kental. Rendemen ekstrak yang diperoleh sebesar $21,403 \%$.

\section{Pengamatan Organoleptik dan Mikroskopis Simplisia dan Ekstrak Etanol $70 \%$ Daun $C$. amblycarpa \\ Parameter organoleptik dan mikroskopik} dibutuhkan untuk pengenalan awal dan karakterisasi simplisia dan ekstrak. Parameter yang diamati meliputi bentuk, warna, bau dan rasa dari simplisia dan ekstrak etanol 70\% daun C. amblycarpa (Depkes RI, 1995). Data yang diperoleh dapat digunakan sebagai standar bahan baku simplisia dan ekstrak etanol $70 \%$ daun C. amblycarpa yang baik sebelum digunakan untuk pengujian tahap lanjut. Hasil pemeriksaan organoleptik dapat dilihat pada tabel 1. Fragmen pengenal $C$. amblycarpa dapat dilihat pada gambar 1 .

\section{Standarisasi Serbuk dan Ekstrak Etanol 70\% Daun C. amblycarpa}

Penetapan kadar air pada sebuk simplisia dan ekstrak dilakukan untuk mengetahui kadar air dari serbuk simplisia dan ekstrak dimana kadar air serbuk simplisia dan ekstrak merupakan persentase dari perbandingan volume air hasil destilasi dengan bobot serbuk simplisia atau ekstrak yang digunakan pada saat penetapan kadar air.

Penetapan kadar air serbuk simplisia dan ekstrak dilakukan dengan menggunakan metode destilasi dengan pelarut toluena yang dilaksanakan selama 15 menit dimana metode ini dipilih untuk menetapkan kadar air sampel yang mengandung minyak atsiri. 
Tabel 1. Hasil Pemeriksaan Organoleptik Serbuk dan Ekstrak Etanol 70\% Daun C. amblycarpa

\begin{tabular}{lcc}
\hline \multirow{2}{*}{ Parameter Organoleptik } & \multicolumn{2}{c}{ Hasil Uji } \\
\cline { 2 - 3 } & Serbuk Simplisia & Ekstrak Etanol 70\% \\
\hline Bentuk & Serbuk halus & Kental \\
Warna & Hijau kecoklatan & Coklat kehitaman \\
Bau & Khas aromatik jeruk limau; & aroma keras \\
Rasa & Aroma karamel dengan sedikit \\
Mula-mula terasa tawar, lama- & aroma jeruk limau \\
& lama agak menggigit & Agak pahit \\
\hline
\end{tabular}

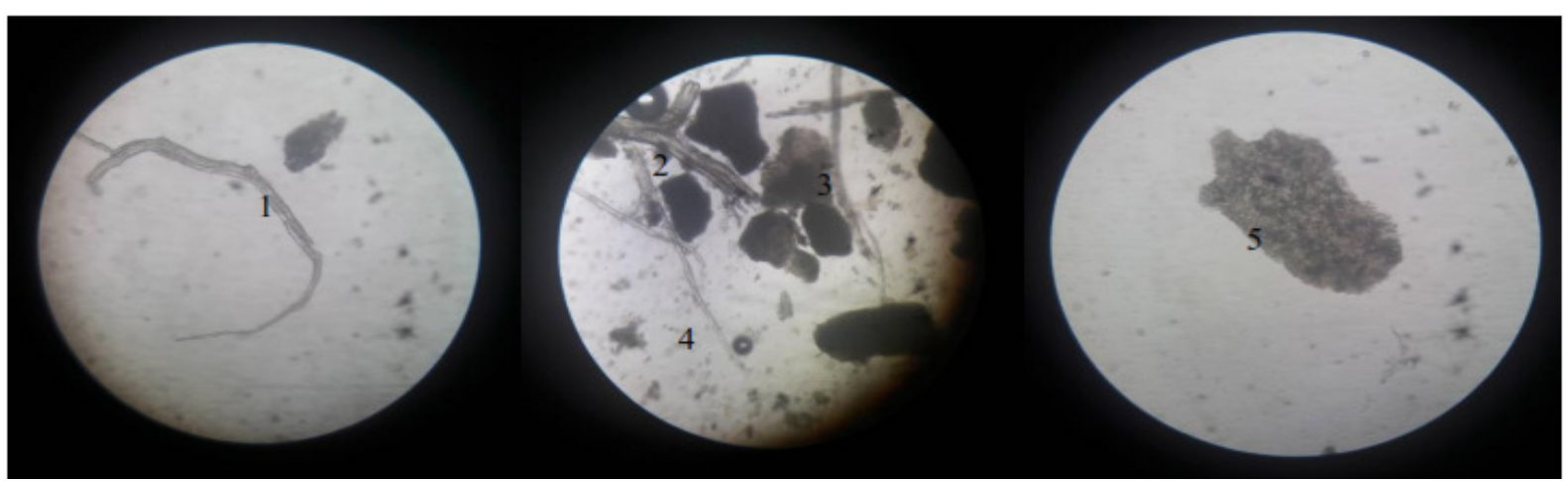

Gambar 1. Hasil Pengamatan Mikroskopik Serbuk Daun C. amblycarpa (Perbesaran 10x40)

Keterangan : (1) Fragmen rambut penutup; (2) Fragmen pembuluh kayu; (3) Fragmen epidermis atas; (4) Serabut; (5) Fragmen epidermis bawah dengan stomata

Tabel 2. Hasil Standarisasi Serbuk dan Ekstrak Etanol 70\% Daun C. amblycarpa

\begin{tabular}{lcc}
\hline \multirow{2}{*}{ Parameter Uji } & \multicolumn{2}{c}{ Hasil Uji } \\
\cline { 2 - 3 } \multicolumn{1}{c}{ Kadar abu total } & Serbuk Simplisia & Ekstrak Etanol 70\% \\
Kadar abu tidak larut asam & $9,732 \% \pm 0,864 \%$ & $9,152 \% \pm 1,521 \%$ \\
Kadar abu larut air & $0,597 \% \pm 0,0021 \%$ & $0,579 \% \pm 0,028 \%$ \\
Kadar air & $1,458 \% \pm 0,028 \%$ & $1,471 \% \pm 0,142 \%$ \\
\hline
\end{tabular}

Tabel 3. Hasil Skrining Fitokimia Serbuk dan Ekstrak Etanol 70\% Daun C. amblycarpa

\begin{tabular}{|c|c|c|c|}
\hline $\begin{array}{l}\text { Golongan } \\
\text { Senyawa }\end{array}$ & Pereaksi/Perlakuan & Perubahan Setelah Penambahan Pereaksi & $\begin{array}{l}\text { Hasil } \\
\text { Uji }\end{array}$ \\
\hline \multirow[t]{3}{*}{ Alkaloid } & Mayer & Tidak terbentuk endapan putih & - \\
\hline & Wagner & Tidak terbentuk endapan & \\
\hline & Bouchardat & Tidak terbentuk endapan coklat kehitaman & \\
\hline Flavonoid & $\begin{array}{l}\text { Asam borat }+ \text { Asam } \\
\text { oksalat }\end{array}$ & $\begin{array}{l}\text { Adanya fluoresensi kuning di bawah UV } \\
366 \mathrm{~nm}\end{array}$ & + \\
\hline Polifenol & $\mathrm{FeCl}_{3} 10 \%$ & Berubah warna menjadi hijau kehitaman & + \\
\hline Tanin & $\mathrm{FeCl}_{3} 5 \%$ & Berubah warna menjadi biru kehitaman & + \\
\hline Glikosida & Lieberman-Burchard & Terbentuk endapan hijau & + \\
\hline Triterpenoid & Lieberman-Burchard & $\begin{array}{l}\text { Tidak terbentuk cincin kecoklatan atau } \\
\text { violet }\end{array}$ & - \\
\hline Steroid & Lieberman-Burchard & Tidak terbentuk cincin biru kehijauan & - \\
\hline Saponin & $\begin{array}{l}\text { Pengocokan } \\
+\mathrm{HCl} \text { pekat }\end{array}$ & $\begin{array}{l}\text { Terbentuk buih tidak stabil } \\
\text { Tidak terbentuk buih }\end{array}$ & - \\
\hline Minyak Atsiri & Diuapkan & Adanya bau khas pada residu & + \\
\hline
\end{tabular}

Keterangan: + : positif

$$
- \text { : negatif }
$$


Kadar air serbuk simplisia yang diperoleh sebesar $4,492 \pm 0,0043 \% \mathrm{~b} / \mathrm{b}$ dan kadar air ekstrak etanol $70 \%$ daun $C$. amblycarpa sebesar 7,9 $\pm 0,023 \%$ b/b Hasil yang diperoleh telah sesuai dengan persyaratan yang tercantum dalam Farmakope Herbal Indonesia yang mana kadar air serbuk simplisia dan ekstrak etanol $70 \%$ daun $C$. amblycarpa tidak lebih dari 10\% (Depkes RI, 2008). Kadar air serbuk simplisia dan ekstrak daun yang kurang dari $10 \%$ dapat meminimalisir tumbuhnya jamur dan kapang serta menghasilkan daya tahan penyimpanan dan meningkatkan mutu ekstrak etanol 70\% daun C. amblycarpa (Zainab et al., 2016)

\section{Penetapan kadar abu pada serbuk simplisia dan ekstrak etanol 70\% daun C. amblycarpa}

Kadar abu menggambarkan adanya kandungan mineral internal dan eksternal pada serbuk maupun ekstrak yang diperoleh dari preparasi awal hingga diperoleh ekstrak etanol $70 \%$ daun C. amblycarpa yang mana metode ini didasarkan atas pemanasan sampel pada temperatur dimana senyawa organik dan turunannya terdestruksi dan menguap (Depkes RI, 2000). Dalam penelitian ini diperoleh kadar abu serbuk simplisia adalah 9,732\% \pm $0,864 \%$ dan ekstrak sebesar $9,152 \% \pm 1,521 \%$ (Zainab et al., 2016). Hasil standarisasi ekstrak etanol $70 \%$ daun C. amblycarpa mendekati nilai kadar abu total ekstrak daun $C$. hystrix yakni sebesar $8,40 \% \pm 0,0397 \%$ dan kadar abu tidak larut asam sebesar $0,52 \% \pm 0,3117 \%$ (Putri, 2017). Hasil standarisasi serbuk simplisia dan ekstrak disajikan pada tabel 2.

\section{Skrining Fitokimia Ekstrak Etanol $\mathbf{7 0 \%}$ Daun C. amblycarpa}

Hasil pengamatan skrining fitokimia dapat dilihat pada tabel 3. Berdasarkan hasil skrining fitokimia, senyawa yang terkandung dalam ekstrak etanol $70 \%$ daun C. amblycarpa meliputi flavonoid, polifenol, tanin, glikosida dan minyak atsiri. Golongan senyawa tersebut sama seperti golongan senyawa yang terkandung pada tanaman genus Citrus lainnya seperti $C$. hystrix yang mengandung flavonoid, polifenol, tanin, saponin, alkaoid, glikosida, fitosterol, dan karbohidrat (Ali et al., 2015).

Polifenol merupakan golongan senyawa dengan sebaran paling banyak di seluruh tumbuhan. Senyawa polifenol memiliki aktivitas sebagai antioksidan dimana berdasarkan struktur aglikosidanya senyawa polifenol dapat dibagi ke dalam kelompok asam fenolik, flavonoid, polifenol amida, dan polifenol lainnya yang memiliki ciri khas tersendiri (Tsao, 2010). Kandungan senyawa polifenol yang terdapat pada ekstrak etanol $70 \%$ daun C. amblycarpa adalah flavonoid. Secara umum kandungan flavonoid yang terdapat pada Citrus meliputi nobiletin, hesperidin, naringin, hesperitin, dan rutin (Sidana et al., 2013). Sedangkan Hodgson (1967) menyebutkan bahwa C. amblycarpa memiliki kandungan flavonoon glikosida meliputi didymin, hesperidin, naringin, narirutin, neohesperidin, dan poncerin. Banyak penelitian yang membuktikan aktivitas senyawa golongan flavonoid pada Citrus seperti antikarsinogenik, kardiovascular, hiperglikemi, antiinflamasi, antialergi, analgesik, antibakteri, dan antidepresan. (Berho et al., 1998).

Senyawa Tanin adalah senyawa polifenol yang berasal dari tumbuhan yang memiliki rasa pahit dan kelat (Makkar, 2003). Secara umum tanin dapat ditemukan pada seluruh bagian tumbuhan genus Citrus dan memiliki konsentrasi terbesar pada daun. Konsentrasi tanin pada daun tanaman genus Citrus berada pada antara 0,53-1,44\% (Ezeabara et al., 2014).

Skrining fitokimia juga membuktikan adanya kandungan dlikosida pada ekstrak etanol $70 \%$ daun C. amblycarpa, dimana diduga senyawa glikosida yang terdapat pada tanaman $C$. amblycarpa merupakan glikosida flavonoid. Senyawa glikosida flavonoid yang terdapat dalam jumlah besar pada tanaman Citrus yaitu neohesperidin, naringin, neoeriocitrin, dan poncirin yang mana senyawa ini memiliki peran menimbulkan rasa pahit pada jeruk (Wang et al., 2017).

Senyawa glikosida flavonoid memiliki sifat farmakokinetik yaitu kecenderungan membentuk ikatan dengan protein plasma yang rendah sehingga konsentrasi senyawa dalam darah apabila dikonsumsi dapat bertahan lebih lama dimana sifat farmakokinetik ini merupakan sifat yang diinginkan dalam suatu obat. Senyawa glikosida flavonoid yang terdapat pada tanaman Citrus memiliki berbagai aktivitas farmakologi seperti antioksidan, antikanker dan antitumor, hepatoprotektif, antiinlamasi, antidiabetes, antiviral, antibakteri dan antifungal (Xiao et al., 2016). 
Secara umum kandungan minyak atsiri pada daun Citrus adalah linalool dengan persentase $36-66 \%$ diikuti dengan linalil asetat. Selain itu komponen terpen, alkohol, aldehid, dan asetat juga ditemukan pada minyak atsiri Citrus seperti $\beta$-myrcene, $\beta$ pinene, sabinene, ocimene, terpinene, terpinolene, neral, geranial, geraniol, nerol, $\alpha$ terpineol, neril asetat, dan geranil asetat (Wolffenbuttel et al., 2015). Namun, belum dapat dipastikan persentase kandungan senyawa tersebut pada minyak atsiri yang terkandung pada ekstrak etanol $70 \%$ daun $C$. amblycarpa.

\section{SIMPULAN DAN SARAN}

\section{Simpulan}

Serbuk simplisia dan ekstrak etanol 70\% daun $C$. amblycarpa yang diperoleh telah memenuhi standar ekstrak simplisia dilihat dari parameter rendemen ekstrak, kadar air ekstrak, kadar abu total, dan kadar abu tidak larut asam dari serbuk dan ekstrak. Skrining fitokimia membuktikan ekstrak etanol $70 \%$ daun $C$. amblycarpa mengandung senyawa flavonoid, polifenol, tanin, glikosida serta minyak atsiri.

\section{Saran}

Hal yang menjadi saran untuk penelitian selanjutnya adalah untuk melakukan penetapan kadar total flavonoid dan total fenol ekstrak etanol $70 \%$ daun C. amblycarpa. Selain itu, perlu dilakukan isolasi senyawa flavonoid, polifenol, tanin, glikosida, serta minyak atsiri dan identifikasi senyawa penyusun minyak atsiri sehingga dapat digunakan untuk memprediksi aktivitas ekstrak etanol $70 \%$ C. amblycarpa.

\section{UCAPAN TERIMAKASIH}

Penulis mengucapkan terima kasih kepada seluruh staf dosen pengajar serta laboran di laboratorium farmakognosi, fitokimia dan analisis program studi Farmasi, Fakultas Matematika dan Ilmu Pengetahuan Alam, Universitas Udayana, serta keluarga Bapak Dewa Made Murtika selaku pemilik tanaman C. amblycarpa (Hassk.) Osche sebagai sampel penelitian.

\section{DAFTAR PUSTAKA}

Ali, M., Akhter, R., Narjish, S. N., Shahriar, dan M., Bhuiyan, M. A., 2015, Studies of Preliminary Phytochemical Screening, Membrane Stabilizing Activity, Trombolitic Activity, and InVitro Antioxidant Activity of Leaf Extract of Citrus hystrix, International Journal of Pharmaceutical Science and Research, 6(6): 2367-2374.

Berho, Tisserat, M., B., Kanes, K., dan Vandercook, C., 1998, Survey of Phenolic Compounds Produced in Citrus, United States Department of Agriculture, USA

Buhian, W. P. C., Rubio, R. O., Valle-Jr, D. L., dan Puzon, J. J. P., 2016, Bioactive Metabolite Profiles and Antimicrobial Activity of Ethanolic Extracts from Muntingia calabura L. Leaves and Stems, Asian Pasific Journal of Tropical Biomedicine, 2(8): 682-685.

Ciulei, 1984, Methodology for Analysis of Vegetables and Drugs. Faculty of Pharmacy Bucharest Rumania, Rumania.

Depkes RI, 1995, Materia Medika Indonesia, Jilid VI, Departemen Kesehatan Republik Indonesia, Jakarta.

Depkes RI, 2000, Parameter Standar Umum Ekstrak Tumbuhan Obat, Edisi I, Departemen Kesehatan Republik Indonesia, Jakarta.

Depkes RI, 2008, Farmakope Herbal Indonesia, Edisi I, Departemen Kesehatan Republik Indonesia, Jakarta.

Diniatik, 2015, Penentuan Kadar Flavonoid Total Ekstrak Etanolik Daun Kepel (Stelechocarpus burahol (Bl.) Hook F. \& Th.) dengan Metode Spektrofotometri, Kartika-Jurnal Ilmiah Farmasi, 3(1): 1-5.

Ezeabara, C., Okeke, C. U., Ilodibya, C. V., dan Azagba, B. O., 2014, Determination of Tannin Content in Various Part of Six Citrus Spesies, Journal of Scientific Research and Report, 3(10): 1384-1392.

Hodgson, R. W., 1967, Horticultural Varieties of Citrus. In: W. Reuther, H.J. Webber, and L.D. Batchelor, The Citrus Industry, University of California, Berkeley. 
Jaiswal, S. K., Gupta, V. K., Siddiqi, N. J., Pandey, R. S., dan Sharma, B., 2015, Hepatoprtective Effect of Citrus limon Fruit Extract Against Carbofuran Induced Toxicity, Chinese Journal of Biology, 2015:1-10.

Laksmiani, N. P. L., Susanti, N. M. P., Widjaja, I. N. K., Rismayanti, A. A. M. I., Wirasuta, I. M. A. G., 2015, Pengembangan Metode Refluks Untuk Ekstraksi Andrografolid Dari Herba Sambiloto, Jurnal Farmasi Udayana, 4(2): 82-90.

Makkar, H. P. S., 2003, Tannin Assays, Effects and Fate of Tannins, Strategies to Overcome Detrimental Effects of Feeding Tannin-Rich Tree and Shrub Foliage, Small Ruminant Research, 49: 241-256.

Mulyani, S. dan Hutabarat, M. M., 2009, Analisis GC-MS dan Daya Anti Bakteri Minyak Atsiri Citrus amblycarpa (Hassk) Ochse, Majalah Farmasi Indonesia, 20(3): 127-132.

Poelongan, M., Andriani, K., Susanti, I., dan Komala, M., 2007, Uji Daya Antibakteri Ekstrak Etanol Batang Bungur (Lagerstormenia speciosa Pers) Terhadap Staphylococcus aureus dan Eschericia coli Secara In-Vitro, Laporan Penelitian, Fakultas Pertanian Institut Pertanian Bogor, Jawa Barat.

Putra, I. G. S, 1999, Taru Pramana Khasiat Tanam-tanaman untuk obat Tradisional, PT. Upada Sastra, Denpasar.

Putri, D. E., 2017, Standarisasi Simplisia dan Ekstrak Etanol Daun Jeruk Purut (Citrus hystrix DC), Skripsi, Universitas Andalas, Padang.

Samraj, S. dan Rajamurgugan, S., 2017, Qualitative and Quantitative Estimation of Bioactive Compound and Antioxidant Activity in Citrus hystrix, International Journal of Engineering Science and Computing, 7(6): 13154-13163.

Seidel, V, 2008, Initial and Bulk Extraction, Sarker, S. D., Latif, Z. and Gray, A. I., Natural Products Isolation, Humana Press, New Jersey, 33-34.

Sidana, J., Saini, V., Dahiya, S., Nain, P., dan Bala, S., 2013, A Review on Citrus"The Boon of Nature", International Journal of Pharmaceutical Science Review and Research, 18(2): 20-27.
Triyono, K., 2013, Keanekaragaman Hayati dalam Menunjang Ketahanan Pangan, Jurnal Inovasi Pertanian, 11(1): 12-22.

Tsao, R., 2010, Chemistry and Biochemistry of Dietary Polyphenol, Nutrients, 2: 12311246.

Vijayalakshmi, R. dan Ravindhran, R., 2012, Preliminary Comparative Phytochemical Screening of Root Extracts of Diospyrus ferrea (Wild.) Bakh and Aerva lanata (L.) Juss. Ex Schultes, Asian Journal of Plant Science and Research, 2(5): 583.

Wadood, A., Ghufran, N., Jamal, S.B., Naeem, M., Khan, A., Ghaffar, R., dan Asnad, 2013, Phytochemical Analysis of Medicinal Plants Accurring in Local Area of Mardan, Biochemistry and Analytical Biochemistry, 2(4): 1-4.

Wang, S., Yang, C., Tu, H., Zhou, J., Liu, X., Cheng, Y., Luo, J., Deng, X., Zhang, H., Xu, J., 2017, Characterization andMetabolic Diversity of Flavonoids in Citrus Species, Scientific Reports, 7(10549): 1-10.

Wells, M. J. M., 2003, Principles of Extraction and The Extraction of Semivolatile Organics from Liquids, Trapp, T., Zajul, M., Sample Preparation Techniques in Analytical Chemistry, John Wiley \& Sons, Inc.,New Jersey, 32-225.

Wolffenbuttel, A. N., Zamboni, A., M. DosSantos, K., Borille, B. P., Augustin, O., A., Mariotti K. C., Leal M. B., dan Limberger, L. P., 2015, Chemical Components of Citrus Essential Oil from Brazzil, The Natural Products Journal,5(1): 14-27.

Xiao, J., Capanoqlu, E., Jassbi, A. R., Miorn, A., 2015, Advance on the Flavonoid Cglycosides and Health Benefits, Dietary Phytochemicals: Nutrition and Health, 29(56): S29-S45.

Yi, L., Ma, S., dan Ren, D. Phytochemical and Bioactivity of Citrus flavonoid: A Focus on Antioxidant, Antiinflamatory, Anticancer, dan Cardiovascular Protection Activities, Phytochemistry Reviews, 16(3):479-511.

Zainab, Sulistyani, dan N., Anisaningrum, 2016, Penetapan Parameter Standarisasi Non Spesifik dan Spesifik Ekstrak Daun Pacar Kuku, Penetapan Parameter Standarisasi, 13(2): 212-226. 